\title{
Genes for Cognitive Function: Developments on the $\mathrm{X}$
}

\author{
Jozef Gécz ${ }^{1,2,4}$ and John Mulley ${ }^{1,3}$ \\ ${ }^{1}$ Department of Cytogenetics and Molecular Genetics, Centre for Medical Genetics, Women's and Children's Hospital (WCH), \\ North Adelaide, SA 5006, Australia; ${ }^{2}$ Department of Pediatrics, ${ }^{3}$ Department of Genetics, University of Adelaide, \\ Adelaide, Australia
}

\begin{abstract}
Developments in human genome research enabled the first steps toward a molecular understanding of cognitive function. That there are numerous genes on the $\mathrm{X}$ chromosome affecting intelligence at the lower end of the cognitive range is no longer in doubt. Naturally occurring mutations have so far led to the identification of seven genes accounting for a small proportion of familial nonspecific X-linked mental retardation. These new data indicate that normal expression of many more X-linked and autosomal genes contribute to cognitive function. The emerging knowledge implicating genes in intracellular signaling pathways provides the insight to identify as candidates other X-linked and autosomal genes regulating the normal development of cognitive function. Recent advances in unravelling the underlying molecular complexity have been spectacular but represent only the beginning, and new technologies will need to be introduced to complete the picture.
\end{abstract}

The excess of males over females in the lower range of IQ distribution has long been recognized (Penrose 1938). Recent large-scale longitudinal studies have shown male excess at both ends of the distribution of IQ scores. Moreover, these differences in variance between the two sexes (males show consistently higher variance), although generally small, are stable over time (Hedges and Nowell 1995). These observations are consistent with the notion that at least a proportion of cognitive function as measured by current tests is determined by genes on the $\mathrm{X}$ chromosome. Although the contribution of X-linked genes to increased IQ remains an area of controversy (Lehrke 1972; Turner and Partington 1991; Morton 1992; Turner 1996; Lubs et al. 1999), the fact that X-linked genes decrease IQ of males is now well established, especially in families segregating X-linked mental retardation (XLMR).

\section{Classification and Incidence of Mental Retardation}

Mental retardation (MR) is defined as an IQ $<70$ and is subdivided into ranges: borderline ( 70), mild (50-69), moderate (35-49), severe (20-34), and profound $(<19)$. Prevalence is $2 \%-3 \%$ of the population (for review, see McLaren and Bryson 1987; Raynham et al. 1996; Crow and Tolmie 1998). MR can be a component of a more complex syndrome (e.g., Down syndrome, fragile $\mathrm{X}$ syndrome, ATR-X syndrome), metabolic disorder (e.g., phenylketonuria), or neuromuscular disorder (e.g., Duchenne muscular dystrophy), or MR can be an exclusive phenotype affecting only postnatal development of cognitive function (nonspecific mental retardation). Given the ease of expression of X-linked dis-

\footnotetext{
${ }^{4}$ Corresponding author.
}

E-MAIL jgecz@mad.adelaide.edu.au; FAX 61882047342. orders in hemizygous males, the X-chromosome has become an obvious focus for beginning to map and identify genes for syndromal and nonspecific MR. Syndromal XLMR has been reviewed elsewhere (Lubs et al. 1999) and lies outside the scope of the present discussion. The purpose of this review is to summarize current knowledge of the molecular basis for nonspecific mental retardation.

The first nonspecific XLMRs were mapped in 1988 (Arveiler et al. 1988; Suthers et al. 1988). Whereas syndromal XLMR is named on the basis of the most distinctive clinical features or eponomously after the dysmorphologists who described the associated distinctive clinical features, an alternative nomenclature system needed to be devised for nonspecific XLMR. Nonspecific XLMR is defined as a nonprogressive genetically heterogeneous condition that affects cognitive function in the absence of other distinctive dysmorphic, metabolic, or neurologic features. The symbol MRX was adopted for nonspecific X-linked MR, and sequential MRX numbers beginning with MRX1 (Suthers et al. 1988) were applied to families that satisfied MRX criteria (Mulley et al. 1992).

The prevalence of all XLMRs is estimated to be 1.66/1000 males (Glass 1991; Turner et al. 1996). Estimated incidence for MRX is 0.9-1.4/1000 males (Kerr et al. 1991), a figure much higher than $0.22 / 1000$ for fragile X syndrome (Turner et al. 1996), the most common inherited familial MR. Although MRX is collectively more common than fragile $\mathrm{X}$ syndrome, each MRX is individually rare. The most common MRX remains FRAXE MR, associated with amplification of CCG within FMR2.

Currently, there are nearly 900 autosomal and X- 
linked entries with MR as an exclusive or inclusive phenotype in the OMIM database (http://www.ncbi.nlm. nih.gov/Omim/). In $~ 75 \%$ of these, MR is a component of a syndromal autosomal recessive or dominant phenotype. There is no known autosomal form of familial nonspecific MR similar to MRX. A recent update on XLMR (Lubs et al. 1999) reviewed 178 XLMR entries of which 120 are syndromal (MRXS) and 58 are nonspecific (MRX). Recent new ascertainments of MRX families have increased the total to 75 at August 1999 (the Ninth International Workshop on Fragile X Syndrome and X-linked Mental Retardation, Strasbourg, France 1999). Although these families are slowly accumulating, families of sufficient size for gene localization and assignment of an MRX symbol remain extremely rare, emphasising the need for international collaboration. Numerous smaller families are also undoubtedly Xlinked, including some containing affected females. Affected females documented in the larger pedigrees could be affected as a result of skewed X-chromosome inactivation or partial dominance of the molecular defect.

\section{Resources and Approaches Leading to Gene Identification}

Since the publication of MRX1 (Suthers et al. 1988), a significant resource of mapped MRX families has been established, and additions remain ongoing. In the recent past this was the point when the family study was abandoned. The gene localization determined by linkage in single families was too broad for positional cloning; very few of the potential candidate genes had been discovered, and there were no single obvious positional candidate genes to screen for mutations from among the numerous genes that were known and expressed in brain. Moreover, refinement to gene localization was not possible because the individual MRX families could not be lumped together on the basis of their "common" phenotype. The approach has changed little in 5 years since Mandel (1994) lamented that gene identification "will ultimately depend on systematic screening of many probands for mutations in many candidate genes." What has changed drastically has been the availability of vast resources arising from the Human Genome Project (Fig. 1).

An important focus of recent research has become the identification of genes affected by X-chromosomal rearrangements in patients with nonspecific MR. The chromosomal rearrangements include balanced (at the level of light microscopy) X; autosome translocations, where the normal $X$ is preferentially inactivated in affected females, X-chromosome inversions in affected males, and submicroscopic deletions in affected males. $\mathrm{X}$-chromosome genes structurally affected by breakpoints or lost by deletion represent naturally occurring human gene knockouts probably accounting for most

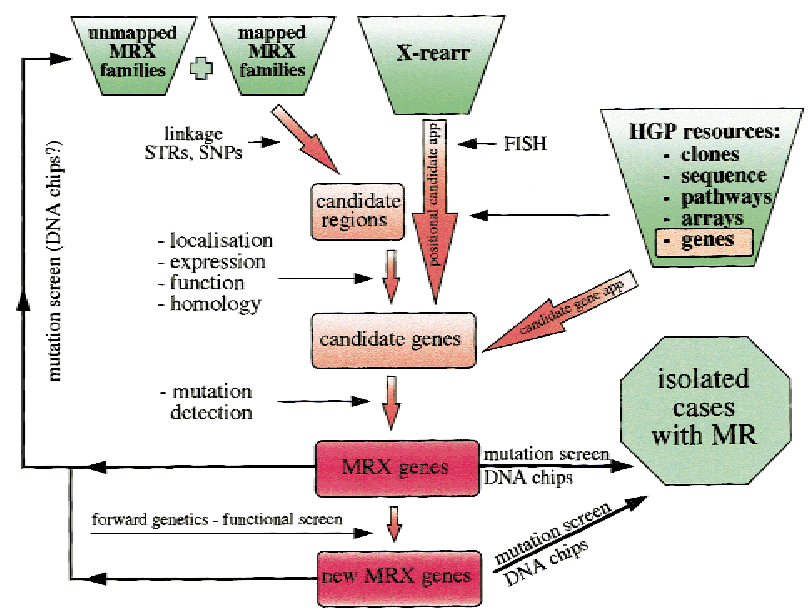

Figure 1 A flow diagram of the current approaches and resources available for mapping and identification of MRX genes. Currently two bags of resources are widely used, MRX families (large, $\operatorname{lod}>2$, and small $\operatorname{lod}<2$ ) and individual patients with $X$ aberrations. Undoubtedly new technologies will play a major part in speeding up the whole process on different levels: linkage analysis (automated genotyping, SNP analysis); candidate gene characterization (based on finished or a draft human genome sequence) and expression analysis (ESTs, SAGE, CDNA microarrays); and high-throughput mutation detection technology (DNA chips for known and new mutations, direct candidate gene mutation screen). Application of forward genetics techniques (search for interacting proteins, pathways) will add yet another dimension to the scheme. With this knowledge, resources, and technologies, the identification of autosomal genes involved in aspects of cognitive function and understanding of its molecular basis will make a giant leap forward.

of the symptoms in the patients who have the chromosomal aberrations. Moreover, these same genes become instant candidates for familial MRX mapping by linkage to the same locations. This approach represents a lesson learned from the early positional cloning of genes for other X-linked disorders such as Duchenne muscular dystrophy. Precise determination of the breakpoint at the level of the DNA sequence is facilitated by the availability of detailed physical maps (National Center for Biotechnology Information, Whitehead Institute at the Massachusetts Institute of Technology, Sanger Center, Washington University, Max Planck Institute Berlin), clone reagents (idem; Roswell Park) and FISH, partial gene sequences (ESTs, Unigene clusters, THCs), rapidly growing genomic DNA sequence data in the public domain (http:// www.ncbi.nlm.nih.gov/genome/seq/), and overall globalization (World Wide Web) of human genome research. The human X chromosome is currently one of the best characterized human chromosomes with $>35 \%$ of its estimated $150-$ to $160-\mathrm{Mb}$ genomic sequence completed (>56.7 $\mathrm{Mb}$ as of 9/9/99; http:// www.ncbi.nlm.nih.gov/genome/seq/).

Two of the genes for familial MRX were identified by positional cloning from within deletions. The first, 
FMR2, had a CCG repeat at its 5' end associated with FRAXE. Expansion of FRAXE CCG repeats beyond a threshold that resulted in CpG methylation of this region was shown to silence FMR2 transcription (Gécz et al. 1996, 1997b). The other, IL1RAPL, was interrupted by a deletion in family MRX34 and then confirmed as the specific gene affecting cognitive function by detection of a nonsense mutation in a second MRX family (Carrie et al. 1999). Another two genes were identified by positional cloning of the gene at the $\mathrm{X}$ breakpoint of $\mathrm{X}$; autosome translocations in mentally impaired females. Oligophrenin 1 (OPHN1; Billuart et al. 1998) and tetraspanin 2 (TM4SF2; Zemni et al. 2000) then became instant candidates for familial XLMR, and they were independently confirmed as genes for XLMR by detection of mutations in families linked to the same regions. The three remaining genes, GDI1 (D'Adamo et al. 1998), PAK3 (Allen et al. 1998), and RPS6KA3 (Merienne et al. 1999), were identified by the positional candidate approach. Genes within minimal intervals determined from linkage mapping in MRX families are chosen as candidates to be screened for mutation in relevant families based on criteria like expression in brain, tentative involvement in signalling pathways (see below), or similarity to a known MRX gene. Once a mutation within a given gene is identified in one MRX family, other MRX families from the region are screened to determine the frequency of that gene as a cause of MRX in MRX families mapping to the same regions (Fig. 1).

\section{How Many Genes for MR?}

Early delineation of the number of MRX genes on the basis of nonoverlapping localizations led to the minimum estimate of eight (Gedeon et al. 1996). This has now been increased to 11, with 7 identified MRX genes plus 4 nonoverlapping regional localizations determined by linkage that do not yet overlap identified MRX genes (Fig. 2). Because not all MRX families have mutations within known MRX genes localizing to the same interval, the minimum number of different MRX genes can be conservatively estimated at 22, by merely doubling the genes in each interval defined so far.

Morton et al. $(1977,1978)$ predicted at least 325 autosomal genes and at least $17 \mathrm{X}$-linked genes causing nonspecific MR based on a mutation rate of 0.008 per gamete or $<2.4 \times 10^{-5}$ per locus. This estimate was later argued, especially regarding the number of $\mathrm{X}$ linked genes and, in particular, those implicated in MRX (Turner and Partington 1991; Morton 1992; Turner 1996). Empirical estimates of the minimum number of loci (Fig. 2) are similar to Morton's original prediction of at least 17 (but maximum 25) genes for MRX. Given that only a small proportion of MRX families ( $12 \%$ or 9 of $\sim 75$ reported; Table 1 ) have been identified with a mutation in one of the seven presently
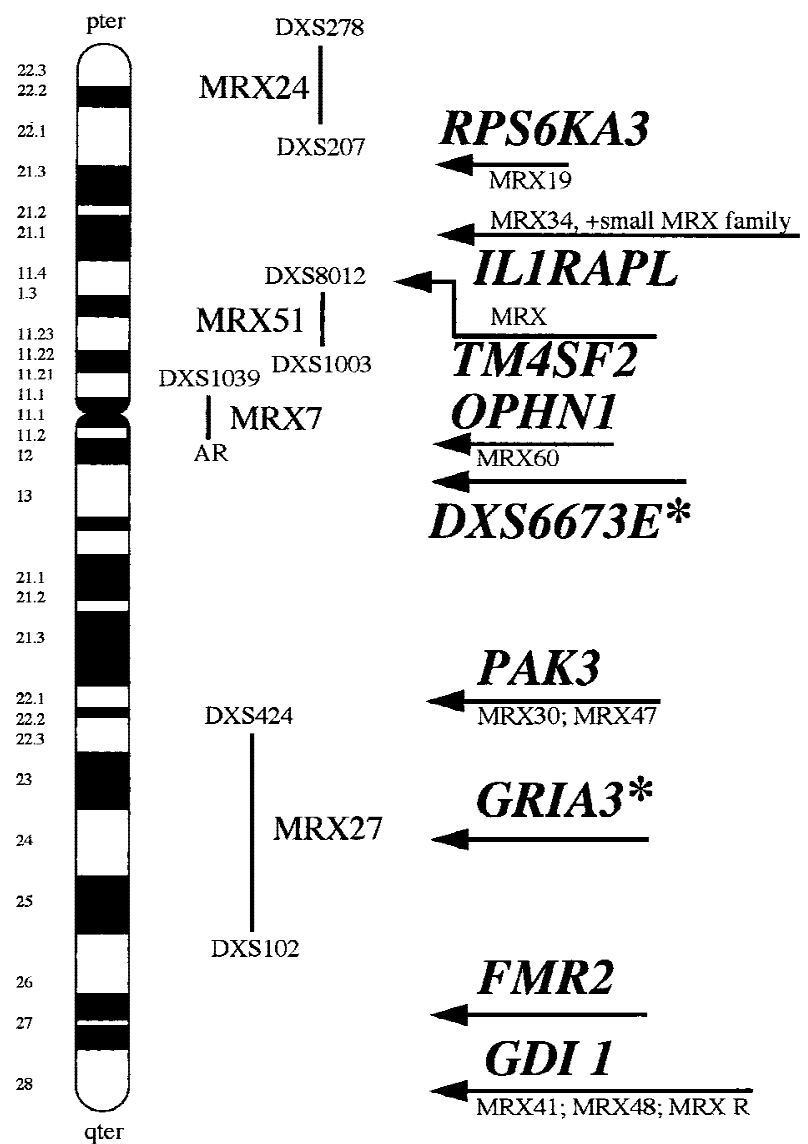

Figure 2 Ideogram of the $X$ chromosome showing the position of the seven known MRX genes, two candidate MRX genes [isolated from $\mathrm{X}$; autosome translocation breakpoints, indicated by an asterisk $\left.\left({ }^{*}\right)\right]$, and four additional nonoverlapping intervals shown by corresponding MRX family linkage intervals. These data indicate that a minimum number of 11 (or 12 when including the candidate MRX gene DXS6673E) MRX loci exist on the X chromosome. Given the fact that only single families from a particular interval were found to have a mutation in any one of the currently identified MRX genes, the minimal number of MRX genes will at least double, that is, reach 22 . The MRX numbers under and above the arrows indicate the individual MRX families with mutations in that particular MRX gene (e.g., MRX19 for RPS6KA3). The vertical bars show minimal linkage intervals of corresponding MRX families with flanking DXS markers indicated.

characterized MRX genes (see below), the overall number of X-linked genes implicated in cognitive functions may be substantially greater than that indicated in Figure 2. Additionally, there are at least two genes identified so far from X-chromosome rearrangement breakpoints, associated with MRX, that have not yet been found mutated in MRX families (van der Maarel et al. 1996; Gécz et al. 2000); however, involvement of the autosomal breakpoint has not been excluded in these cases. Based on these data and numerous documented cases of X-chromosome rearrangements with unique breakpoints, all associated with MR, we may speculate that the number of MRX genes may easily exceed 100 . 
Table 1. Cloned MRX Genes

\begin{tabular}{|c|c|c|c|c|}
\hline Year & MRX gene & Function & MRX mutation(s) & Reference \\
\hline 1996 & FMR2 & $\begin{array}{l}\text { nuclear protein; putative } \\
\text { transcription activator }\end{array}$ & $\begin{array}{l}\text { FRAXE families; } \\
\text { deletion }\end{array}$ & $\begin{array}{l}\text { Gecz et al. (1996) } \\
\text { Gu et al. (1996) } \\
\text { Gedeon et al. (1995) }\end{array}$ \\
\hline 1998 & GDI1 & Rab GDP-dissociation inhibitor & $\begin{array}{l}\text { MRX41; MRX48; } \\
\text { MRX R }\end{array}$ & $\begin{array}{l}\text { D'Adamo et al. (1998) } \\
\text { Bienvenu et al. (1998) }\end{array}$ \\
\hline 1998 & OPHN1 & Rho-GTPase activating protein & MRX60; $t(X ; 12)$ & Billuart et al. (1998) \\
\hline 1998 & PAK3 & p21 activated kinase & $\begin{array}{l}\text { MRX30 } \\
\text { MRX47 }\end{array}$ & $\begin{array}{l}\text { Allen et al. (1998) } \\
\text { Chelly (1999) }\end{array}$ \\
\hline 1999 & RPS6KA3 $3^{\mathrm{a}}$ & growth factor regulated kinase & MRX19 & Merienne et al. (1999) \\
\hline 1999 & ILIRAPL & $\begin{array}{l}\text { interleukin receptor accessory } \\
\text { protein-like }\end{array}$ & MRX; deletions & Carrie et al. (1999) \\
\hline 1999 & TM4SF2 & integrin associated protein & MRX & Zemni et al. (2000) \\
\hline $\begin{array}{l}1996 \\
1999\end{array}$ & $\begin{array}{l}\text { DXS6673E } \\
\text { GRIA3 }^{\mathrm{b}}\end{array}$ & $\begin{array}{l}\text { unknown } \\
\text { glutamate receptor AMPA type }\end{array}$ & $\begin{array}{l}t(X ; 13) \\
t(X ; 12)\end{array}$ & $\begin{array}{l}\text { van der Maarel et al. (2000) } \\
\text { Gecz et al. (2000) }\end{array}$ \\
\hline
\end{tabular}

New research approaches will need to be developed to achieve complete identification of X-chromosome genes for cognitive function (see below).

Are there any autosomal genes causing only MR? Surely there are; however, no autosomal nonspecific MR genes have been identified as yet. Developments toward identification of these genes lag well behind developments on the $\mathrm{X}$ chromosome that have been enhanced by the relative ease of expression of X-linked recessive disorders. Current research into the identification of autosomal genes is focused on screening patients with idiopathic MR for submicroscopic rearrangements and deletions particularly in telomeric regions. Several such rearrangements have recently been identified (Flint et al. 1995; Slavotinek et al. 1999; Wirth et al. 1999). An approach not yet exploited would be the ascertainment of families with autosomal nonspecific MR from populations in which consanguinity is practiced, because only in such families will it be possible to map by linkage the autosomal recessive gene responsible for MR in single sibships. Autosomal dominant pedigrees with MR do not appear to exist, because except for milder forms, this would be reproductively lethal, and no dominant ones are known from the $\mathrm{X}$ chromosome (where skewed $\mathrm{X}$ inactivation has been excluded). Identification of corresponding autosomal genes for aspects of cognitive function will build on knowledge accumulating in the field of X-linked MR, with X-linked and autosomal loci likely to be coded for proteins in the same molecular pathways. If the number of MRX genes exceeds 100 (or even 22) and if genes essential for normal cognitive function are randomly distributed, then the level of complexity of the underlying molecular basis for cognitive inability will be enormous.
Genes Identified and Molecular Pathways Involved Currently, there are seven genes identified with mutations in MRX families and two genes isolated from X; autosome translocation breakpoints associated with nonspecific mental impairment (Fig. 2; Table 1): FMR2 (Gécz et al. 1996; Gu et al. 1996), GDI1 (D'Adamo et al. 1998); OPHN1 (Billuart et al. 1998), PAK3 (Allen et al. 1998), RPS6KA3 (Merienne et al. 1999), IL1RAPL (Carrie et al. 1999), TM4SF2 (Zemni et al. 2000), DXS6673E, (van der Maarel et al. 1996), and GRIA3 (Gécz et al. 2000). It is intriguing that six of these seven genes (GDI1, OPHN1, PAK3, RPS6KA3, IL1RAPL, and TM4SF2) have been shown to participate in various stages of intracellular signaling (Antonarakis and Van Aelst 1998; Chelly 1999). GDI1 and oligophrenin 1 regulate Rab and Rho GTPases involved in vesicle cycling, neurotransmitter release, cell migration, and neurite outgrowth (Van Aelst and D'Souza-Schorey 1997). PAK3 is one of the downstream effectors of Rho GTPases (Rac and Cdc42) carrying the signal to the actin cytoskeleton (Sells et al. 1997) and MAP kinase cascades including c-Jun amino-terminal kinase 1 (JNK1) and p38 (Bagrodia et al. 1995). Interestingly, one of the other recently identified MRX genes, IL1RAPL (Carrie et al. 1999) participates in the interleukin (IL-1) signaling pathway that involves activation of JNK kinase as well (Bagrodia et al. 1995). RPS6KA3 with some residual activity is associated with MRX after being characterized previously for more severe mutations associated with Coffin-Lowry syndrome (CLS; Trivier et al. 1996). It is a MAPK activated CREB kinase with important cellular function in regulation of immediate-early gene transcription (Xing et al. 1996). TM4SF2, or tetraspanin-2, is an integrinassociated protein that can modulate integrin signal- 
ing and thus participate in regulation of cell motility (Berditchevski and Odintsova 1999) and especially neurite outgrowth (Hemler 1998).

The function of FMR2 (the FRAXE fragile site associated gene) is yet to be deciphered. There is some evidence that FMR2 is a nuclear protein with potential to regulate (activate) transcription (Gécz et al. 1997a) and thus eventually serve as a possible downstream effector of MAP kinase pathways the other MRX genes are part of. Preliminary studies on $\mathrm{fmr} 2$ knockout mice indicate no phenotypic or pathologic abnormalities; however, behavioural studies suggest a defect in tests of conditioned fear (Nelson et al. 1999).

Of the two other candidate MRX genes isolated from X-chromosome breakpoints but not yet found mutated in families (Table 1), the function is not known for the DXS6673E gene. The other, GRIA3, an AMPA type glutamate receptor is yet another major player in postsynaptic signaling via $\mathrm{Ca}^{2+} / \mathrm{calmodulin}$ (CaM) dependant pathway. The crucial role of glutamate receptors in learning and memory has been widely supported (Ozawa et al. 1998). Recent findings on transgenic mice overexpressing a subtype of an NMDA glutamate receptor gene $N R 2 B$ in adult brain that triggered enhanced memory and improved learning further accentuate the role of glutamate receptor mediated pathways in cognitive functions (Tang et al. 1999). In addition to NMDA and metabotropic glutamate receptors, the participation of AMPA class glutamate receptors (of which the GRIA3 gene is a member) in long term potentiation (LTP), a mechanism holding the key to understanding how memories are formed, has now been demonstrated (Shi et al. 1999).

The significance of these cellular signaling pathways for learning and memory is now unfolding. Mutations in members of the cascade are being identified, and their functional consequence studied and correlated with the MR phenotype observed in families with MRX. It appears that most if not all of the MRX genes show prominent expression in the hippocampus. This relatively small structure of the brain has long been considered (Olton et al. 1986) and is presently accepted (Bliss and Collingridge 1993) as the prime region involved in processes of learning and memory. No variations in X-linked genes have been identified that might account for higher IQ ( $>130)$, but such families have not been sought or investigated as the vast majority of mutations drastically affecting function are likely to lower IQ.

\section{Future Directions}

The genetic complexity underlying cognitive function seems to be enormous. The molecular tools and techniques will need to be improved and new approaches developed to move from detection of only genes affecting the extreme phenotype for cognitive function (e.g.,
MRX) to definition of components that modulate fine tuning of cognitive function within the major range of variation. FRAXE MR illustrates the problem involved. Several studies now demonstrate that not all affected individuals (with FRAXE CCG expansion and subsequent silencing of FMR2 gene transcription), often brothers, are concordant for reduction of IQ below 70. Expression of FMR2 in these cases is assumed to be extinguished in the brain, an extrapolation from results of experiments performed on fibroblasts of the same patient (Gécz et al. 1997b). Had there not been the unstable $(\mathrm{CCG})_{\mathrm{n}}$ marker within the FMR2 gene, the association between FMR2 and MR may not have been recognized. This clearly points to other molecular variation (autosomal and/or X-linked) with similar effects on phenotype (IQ) that would be even more difficult to recognize by simple family study than the mild mental impairment associated with FRAXE.

It is a challenge for the future to decipher the complexity underlying human cognitive function. New technologies of large scale expression analysis [SAGE (serial analysis of gene expression), cDNA microarrays, RNA differential display] and associated informatics (Somogyi 1999; Zhang 1999) to organize and analyze these experimental data into meaningful patterns/ pathways might be applied to realize the ultimate goal of determination of all MR genes (X-linked and autosomal). Only then will the beginning of understanding of function in global terms be achievable. We may envisage that based on the growing understanding of Xlinked MR pathology in the not too distant future the forward genetics approaches (search for interacting proteins, interconnected pathways; for review, see Stark and Gudkov 1999) will start to play an increasingly important role in MR gene identification and characterization. Moreover, preliminary studies on transgenic mouse models (such as that of the fmr2 mouse) are encouraging and demonstrate the use of animal transgenics in the understanding of principles and mechanisms of human learning and memory. The intriguing question of what makes us different from our closest mammal and especially primate relatives, the quality (new function) or the quantity (new genes), or both, resurfaces. So far all MRX genes currently identified have homologs in lower species. As to whether they show the same properties across species remains to be investigated.

We may speculate that to keep a complex organ such as the human brain functioning normally requires not one, not two, but hundreds or thousands of genes integrated in such a way that their products function in concert. These complex interactions remain well balanced even under a variety of environmental stimuli. In contrast, malfunction of only a single gene may catastrophically disrupt the balance, 
the lesson learned as genes for MRX are now being discovered.

\section{ACKNOWLEDGMENTS}

We thank Grant Sutherland and Laurent Villard for their critical comments and helpful suggestions. This work has been supported by Australian NH\&MRC and Adelaide WCH Research Foundation grants.

The publication costs of this article were defrayed in part by payment of page charges. This article must therefore be hereby marked "advertisement" in accordance with 18 USC section 1734 solely to indicate this fact.

\section{REFERENCES}

Allen, K.M., J.G. Gleeson, S. Bagrodia, M.W. Partington, J.C. MacMillan, R.A. Cerione, J.C. Mulley, and C.A. Walsh. 1998. PAK3 mutation in nonsyndromic X-linked mental retardation. Nat. Genet. 20: 25-30.

Antonarakis, S.E. and L. Van Aelst. 1998. Mind the GAP, Rho, Rab and GDI. Nat. Genet. 19: 106-108.

Arveiler, B., Y. Alembik, A. Hanauer, P. Jacobs, L. Tranebjaerg, M. Mikkelsen, H. Puissant, L.L. Piet, and J.L. Mandel. 1988. Linkage analysis suggests at least two loci for X-linked nonspecific mental retardation. Am. J. Med. Genet. 30: 473-483.

Bagrodia, S., B. Derijard, R.J. Davis, and R.A. Cerione. 1995. Cdc42 and PAK-mediated signaling leads to Jun kinase and p38 mitogen- activated protein kinase activation. J. Biol. Chem. 270: $27995-27998$.

Berditchevski, F. and E. Odintsova. 1999. Characterization of integrin-tetraspanin adhesion complexes: Role of tetraspanins in integrin signaling. J. Cell Biol. 146: 477-492.

Billuart, P., T. Bienvenu, N. Ronce, V. des Portes, M.C. Vinet, R. Zemni, A. Carrie, C. Beldjord, A. Kahn, C. Moraine, and J. Chelly. 1998. Oligophrenin 1 encodes a rho GAP protein involved in X-linked mental retardation. Pathol. Biol. (Paris) 46: 678 .

Bliss, T.V. and G.L. Collingridge. 1993. A synaptic model of memory: Long-term potentiation in the hippocampus. Nature 361: 31-39.

Carrie, A., L. Jun, T. Bienvenu, M.C. Vinet, N. McDonell, P. Couvert, R. Zemni, A. Cardona, G. Van Buggenhout, S. Frints et al. 1999. A new member of the IL-1 receptor family highly expressed in hippocampus and involved in X-linked mental retardation. Nat. Genet. 23: 25-31.

Chelly, J. 1999. Breakthroughs in molecular and cellular mechanisms underlying X-linked mental retardation. Hum. Mol. Genet. 8: 1833-1838.

Crow, Y.J. and J.L. Tolmie. 1998. Recurrence risks in mental retardation. J. Med. Genet. 35: 177-182.

D’Adamo, P., A. Menegon, C. Lo Nigro, M. Grasso, M. Gulisano, F. Tamanini, T. Bienvenu, A.K. Gedeon, B. Oostra, S.K. Wu, A. Tandon, F. Valtorta, W.E. Balch, J. Chelly, and D. Toniolo. 1998. Mutations in GDI1 are responsible for X linked nonspecific mental retardation. Nat. Genet. 19: 134-139.

Flint, J., A.O. Wilkie, V.J. Buckle, R.M. Winter, A.J. Holland, and H.E. McDermid. 1995. The detection of subtelomeric chromosomal rearrangements in idiopathic mental retardation. Nat. Genet. 9: $132-140$.

Gécz, J., A.K. Gedeon, G.R. Sutherland, and J.C. Mulley. 1996. Identification of the gene FMR2, associated with FRAXE mental retardation. Nat. Genet. 13: 105-108.

Gécz, J., S. Bielby, G.R. Sutherland, and J.C. Mulley. 1997a. Gene structure and subcellular localization of FMR2, a member of a new family of putative transcription activators. Genomics 44: $201-213$.

Gécz, J., B.A. Oostra, A. Hockey, P. Carbonell, G. Turner, E.A. Haan, G.R. Sutherland, and J.C. Mulley. 1997b. FMR2 expression in families with FRAXE mental retardation. Hum. Mol. Genet.
6: 435-441.

Gécz, J., S. Barnett, J. Liu, G. Hollway, A. Donnelly, H. Eyre, H.S. Eshkevari, R. Baltazar, A. Grunn, R. Nagaraja et al. 2000. Characterization of the human glutamate receptor subunit 3 gene (GRIA3), a candidate for bipolar disorder and nonspecific $\mathrm{X}$-linked mental retardation. Genomics (in press).

Gedeon, A.K., A.J. Donnelly, J.C. Mulley, B. Kerr, and G. Turner. 1996. How many X-linked genes for nonspecific mental retardation (MRX) are there? [letter]. Am. J. Med. Genet. 64: $158-162$.

Glass, I.A. 1991. X linked mental retardation. J. Med. Genet. 28: $361-371$.

Gu, Y.H., Y. Shen, R.A. Gibbs, and D.J. Nelson. 1996. Identification of FMR2, a novel gene associated with the Fraxe Ccg repeat and Cpg island. Nat. Genet. 13: 109-113.

Hedges, L.V. and A. Nowell. 1995. Sex differences in mental test scores, variability, and numbers of high-scoring individuals. Science 269: 41-45.

Hemler, M.E. 1998. Integrin associated proteins. Curr. Opin. Cell. Biol. 10: $578-585$.

Kerr, B., G. Turner, J. Mulley, A. Gedeon, and M. Partington. 1991. Nonspecific X linked mental retardation. J. Med. Genet. 28: $378-382$.

Lehrke, R. 1972. Theory of X-linkage of major intellectual traits. Am. J. Ment. Defic. 76: 611-619.

Lubs, H., P. Chiurazzi, J. Arena, C. Schwartz, L. Tranebjaerg, and G. Neri. 1999. XLMR genes: Update 1998. Am. J. Med. Genet. 83: 237-247.

Mandel, J.L. 1994. Towards identification of X-linked mental retardation genes: A proposal. Am. J. Med. Genet. 51: 550-552.

McLaren, J. and S.E. Bryson. 1987. Review of recent epidemiological studies of mental retardation: Prevalence, associated disorders, and etiology. Am. J. Ment. Retard. 92: 243-254.

Merienne, K., S. Jacquot, S. Pannetier, M. Zeniou, A. Bankier, J. Gécz, J.L. Mandel, J. Mulley, P. Sassone-Corsi, and A. Hanauer. 1999. A missense mutation in RPS6KA3 (RSK2) responsible for nonspecific mental retardation [letter]. Nat. Genet. 22: 13-14.

Morton, N.E. 1978. Effect of inbreeding on IQ and mental retardation. Proc. Natl. Acad. Sci. 75: 3906-3908.

. 1992. Genes for intelligence on the X chromosome. J. Med. Genet. 29: 71.

Morton, N.E., D.C. Rao, H. Lang-Brown, C.J. Maclean, R.D. Bart, and R. Lew. 1977. Colchester revisited: A genetic study of mental defect. J. Med. Genet. 14: 1-9.

Mulley, J.C., B. Kerr, R. Stevenson, and H. Lubs. 1992. Nomenclature guidelines for X-linked mental retardation. Am. J. Med. Genet. 43: 383-391.

Nelson, D.L., Y. Gu, K. Yamagata, K. Mcllwain, R. Payor, and H. Zoghby. 1999. A mouse model of FRAXE mental retardation provides detailed study of normal expression and showes behavioral abnormalities. Ninth International Workshop on Fragile Syndrome and X Linked Mental Retardation, Strasbourg, France p. 75.

Ninth International Workshop on Fragile X Syndrome and X Linked Mental Retardation, Strasbourg, France 1999.

Olton, D.S., C.G. Wible, and M.L. Shapiro. 1986. Mnemonic theories of hippocampal function. Behav. Neurosci. 100: 852-855.

Ozawa, S., H. Kamiya, and K. Tsuzuki. 1998. Glutamate receptors in the mammalian central nervous system. Prog. Neurobiol. 54: $581-618$.

Penrose, L.S. 1938. A clinical and genetic study of 1280 cases of mental defect. Special Report Series 229, Medical Research Council, London, UK.

Raynham, H., R. Gibbons, J. Flint, and D. Higgs. 1996. The genetic basis for mental retardation. Q.J. Med. 89: 169-175.

Sells, M.A., U.G. Knaus, S. Bagrodia, D.M. Ambrose, G.M. Bokoch, and J. Chernoff. 1997. Human p21-activated kinase (Pak1) regulates actin organization in mammalian cells. Curr. Biol. 7: 202-210.

Shi, S.H., Y. Hayashi, R.S. Petralia, S.H. Zaman, R.J. Wenthold, K. Svoboda, and R. Malinow. 1999. Rapid spine delivery and 
redistribution of AMPA receptors after synaptic NMDA receptor activation. Science 284: 1811-1816.

Slavotinek, A., M. Rosenberg, S. Knight, L. Gaunt, W. Fergusson, C. Killoran, J. Clayton Smith, H. Kingston, R.H. Campbell, J. Flint, D. Donnai, and L. Biesecker. 1999. Screening for submicroscopic chromosome rearrangements in children with idiopathic mental retardation using microsatellite markers for the chromosome telomeres. J. Med. Genet. 36: 405-411.

Somogyi, R. 1999. Making sense of gene-expression data. Trends Genet. (Suppl.): 17-24.

Stark, G.R. and A.V. Gudkov. 1999. Forward genetics in mammalian cells: Functional approaches to gene discovery. Hum. Mol. Genet. 8: $1925-1938$.

Suthers, G.K., G. Turner, and J.C. Mulley. 1988. A non-syndromal form of X-linked mental retardation (XLMR) is linked to DXS14. Am. J. Med. Genet. 30: 485-491.

Tang, Y.P., E. Shimizu, G.R. Dube, C. Rampon, G.A. Kerchner, M. Zhuo, G. Liu, and J.Z. Tsien. 1999. Genetic enhancement of learning and memory in mice. Nature 401: 63-99.

Trivier, E., D. De Cesare, S. Jacquot, S. Pannetier, E. Zackai, I. Young, J.L. Mandel, P. Sassone-Corsi, and A. Hanauer. 1996. Mutations in the kinase Rsk-2 associated with Coffin-Lowry syndrome. Nature 384: $567-570$.

Turner, G. 1996. Intelligence and the X chromosome. Lancet 347: 1814-1815.

Turner, G. and M.W. Partington. 1991. Genes for intelligence on the X chromosome [letter] J. Med. Genet. 28: 429.

Turner, G., T. Webb, S. Wake, and H. Robinson. 1996. Prevalence of fragile X syndrome. Am. J. Med. Genet. 64: 196-197.

Van Aelst, L. and C. D'Souza-Schorey. 1997. Rho GTPases and signaling networks. Genes \& Dev. 11: 2295-2322.

van der Maarel, S.M., I.H. Scholten, I. Huber, C. Philippe, R.F. Suijkerbuijk, S. Gilgenkrantz, J. Kere, F.P. Cremers, and H.H. Ropers. 1996. Cloning and characterization of DXS6673E, a candidate gene for X-linked mental retardation in Xq13.1. Hum. Mol. Genet. 5: 887-897.

Wirth, J., H.G. Nothwang, S. van der Maarel, C. Menzel, G. Borck, I. Lopez-Pajares, K. Brondum-Nielsen, N. Tommerup, M. Bugge, H.H. Ropers, and T. Haaf. 1999. Systematic characterisation of disease associated balanced chromosome rearrangements by FISH: Cytogenetically and genetically anchored YACs identify microdeletions and candidate regions for mental retardation genes. J. Med. Genet. 36: 271-278.

Xing, J., D.D. Ginty, and M.E. Greenberg. 1996. Coupling of the RAS-MAPK pathway to gene activation by RSK2, a growth factor-regulated CREB kinase. Science 273: 959-963.

Zemni, R., T. Bienvenu, M.C. Vinet, A. Sefiani, A. Carrie, P. Billuart, N. McDonell, P. Couvert, F. Francis, P. Chafey, F. Fauchereau, G. Friocourt, V. des Portes, A. Cardona, S. Frints, A. Meindl, O. Brandau, N. Ronce, C. Moraine, H. van Bokhoven, H.H. Ropers, R. Sudbrak, A. Kahn, J.P. Fryns, C. Beldjord, and J. Chelly. 2000 Identification of a novel gene involved in X-linked mental retardation through investigation of an $\mathrm{X} ; 2$ balanced translocation.Nat. Genet. (in press, 2000)

Zhang, M.Q. 1999. Large-scale gene expression data analysis: A new challenge to computational biologists. Genome Res. 9: 681-688. 


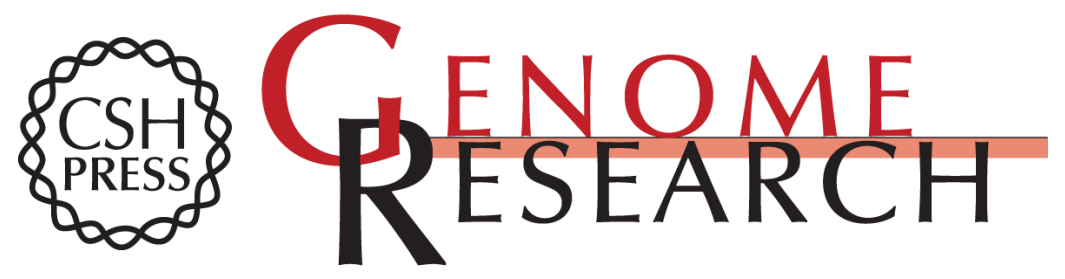

\section{Genes for Cognitive Function: Developments on the X}

Jozef Gécz and John Mulley

Genome Res. 2000 10: 157-163

Access the most recent version at doi:10.1101/gr.10.2.157

References This article cites 45 articles, 14 of which can be accessed free at:

http://genome.cshlp.org/content/10/2/157.full.html\#ref-list-1

\section{License}

Email Alerting Receive free email alerts when new articles cite this article - sign up in the box at the Service top right corner of the article or click here.

\section{Affordable, Accurate Sequencing.}

To subscribe to Genome Research go to: https://genome.cshlp.org/subscriptions 